\title{
Perbandingan Efektifitas Rapid Diagnostic Test (RDT) dengan Pemeriksaan Mikroskop pada Penderita Malaria Klinis di Puskesmus Mubune Kecamatan Likupang Barat
}

\author{
${ }^{1}$ Natanael Ritung \\ ${ }^{2}$ Victor D. Pijoh \\ ${ }^{2}$ Janno B. B. Bernadus
}

\author{
${ }^{1}$ Program Studi Pendidikan Dokter Fakultas Kedokteran Universitas Sam Ratulangi Manado \\ ${ }^{2}$ Bagian Parasitologi Fakultas Kedokteran Universitas Sam Ratulangi Manado \\ Email: natanaelritung2@gmail.com
}

\begin{abstract}
Malaria is still a public health problem worldwide, especially in economically underdeveloped and undeveloped countries. There are several laboratory diagnostic tests for malaria inter alia microscopic examination (thick and thin stained blood smear), rapid diagnostic test (RDT), and polymerase chain reaction (PCR). This study was aimed to compare the effectivity of RDT with of microscopic examination as the gold standard of malaria diagnosis. This was a diagnostic test study. Blood samples were obtained from 38 people of clinical malaria who lived at Likupang Barat from October 2015 to January 2016. The RDT results were compared with the microscopic examination to obtain the sensitivity and specifity levels. The results showed that of the RDT, the sensitivity was $67 \%$, the specifity was $97 \%$, the positive predictive value was $67 \%$, and the negative predictive value was $97 \%$. Conclusion: Rapid diagnostic test was nearly as effective as the microscopic examination of malaria.
\end{abstract}

Keywords: RDT, microscopic examination, sensitivity, specificity

\begin{abstract}
Abstrak: Malaria masih menjadi masalah kesehatan di dunia terutama di negara yang secara ekonomis masih tertinggal dan belum berkembang. Diagnosis laboratorik malaria dapat dilakukan dengan beberapa cara antara lain pemeriksaan mikroskopik yaitu hapusan darah tebal dan hapusan darah tipis, rapid diagnostic test (RDT), dan polymerase chain reaction (PCR). Penelitian ini bertujuan untuk membandingkan tingkat efektifitas antara RDT dengan pemeriksaan mikroskopik yang merupakan baku emas diagnostik malaria. Jenis penelitian ialah uji diagnostik. Sampel darah diambil dari 38 orang dengan klinis malaria di Likupang Barat sejak Oktober 2015 - Januari 2016. Hasil pemeriksaan RDT dibandingkan dengan hasil pemeriksaan mikrsokopik untuk mengetahui tingkat sensivitas dan spesifisitasnya. Hasil penelitian mendapatkan tingkat sensivitas RDT secara umum sebesar $67 \%$, spesifitas sebesar 97\%, nilai duga positif sebesar 67\%, dan nilai duga negatif sebesar 97\%. Simpulan: Pemeriksaan RDT menunjukkan efektivitas dan akurasi yang hampir sama dengan pemeriksaan mikroskopik.
\end{abstract}

Kata kunci: RDT, pemeriksaan mikroskopis, sensitivitas, spesifitas

Malaria merupakan salah satu masalah besar dalam dunia kesehatan di seluruh dunia. ${ }^{1}$ Umumnya malaria ditemukan pada daerah yang secara ekonomis masih tertinggal dan belum berkembang seperti di wilayah Afrika, sebagian di wilayah Asia
Selatan, Amerika Latin, dan Asia Tenggara khususnya Indonesia. ${ }^{2,3}$ Malaria sering menyebabkan kematian pada bayi, balita, ibu hamil dan menduduki ranking 5 dari 10 penyakit utama penyebab kecacatan dan kematian di negara-negara paling miskin., 
Malaria disebabkan oleh parasit dari genus Plasmodium yang menyerang eritrosit dan ditandai dengan ditemukannya bentuk aseksual dalam darah. Terdapat 4 jenis Plasmodium yang dapat menyerang manusia (hospes perantara) antara lain Plasmodium falciparum, Plasmodium vivax, Plasmodium malariae dan Plasmodium ovale. ${ }^{6}$ Penyakit ini ditularkan melalui dua cara, yaitu penularan secara alamiah (natural infection) melalui gigitan nyamuk Anopheles spp (hospes definitif) dan penularan yang tidak alamiah seperti malaria bawaan, serta melalui transfusi darah dan jarum suntik. ${ }^{7}$

World Health Organization (WHO) memperkirakan ada sekitar 2.5 milyar manusia di dunia hidup di wilayah endemis malaria, pada tahun 2006 terdapat 200-300 juta kasus dan lebih dari 880 ribu kematian terjadi akibat malaria setiap tahun. ${ }^{1} \mathrm{Di}$ Indonesia, khususnya Provinsi Sulawesi Utara, malaria masih menjadi penyakit infeksi utama baik di rumah sakit maupun di tingkat puskesmas. ${ }^{4,8}$

Angka kesakitan dan angka kematian akibat malaria harus ditekan dan dicegah sebisa mungkin, agar tercipta masyarakat yang hidup sehat terbebas dari penularan penyakit malaria. Upaya pengendalian malaria meliputi diagnosis dini, pengobatan cepat dan tepat, surveilans dan pengendalian vektor yang kesemuanya ditujukan untuk memutus mata rantai penularan malaria.

Diagnosis malaria didasarkan pada manifestasi klinis (termasuk anamnesis), uji imunoserologis dan ditemukannya parasit (Plasmodium) di dalam darah seorang penderita dengan melakukan pemeriksaan penunjang yang akurat yaitu dengan pemeriksaan laboratorium. Diagnosis laboratorium malaria dilakukan dengan beberapa cara antara lain pemeriksaan mikroskopik yaitu hapusan darah tebal dan hapusan darah tipis, rapid diagnostic test (RDT), dan polymerase chain reaction (PCR). ${ }^{6}$

Pemeriksaan mikroskopik menjadi bakuk emas dalam pemeriksaan laboratorium karena metodenya yang cepat dan murah. Pada pemeriksaan mikroskopik sediaan darah tipis dapat jelas terlihat morfologi plasmodium dibandingkan sediaan darah tebal. Pemeriksaan mikroskopik memiliki keterbatasan dalam mendiagnosis infeksi campuran, infeksi dengan keadaan parasitemia, dan tidak terlatihnya tenaga kesehatan laboratorium. ${ }^{6}$

RDT merupakan suatu pemeriksaan laboratorium yang digunakan untuk mendiagnosis penyakit malaria berdasarkan atas deteksi antigen parasit malaria di dalam darah dengan menggunakan prinsip imunokromatografi. Yang paling sering digunakan ialah dipstick (tes strip) yang dilakukan untuk pengujian antibodi monoklonal yang secara langsung menye-rang target antigen dari parasit tersebut. Bidang ilmu ini telah berkembang dengan cepat dan peningkatan teknis secara terus menerus dapat meningkatkan kemampuan RDT dalam menegakkan diagnosis malaria. ${ }^{7-9}$ Uji diagnostik malaria cepat ini dapat membantu dalam diagnosis malaria dengan mendeteksi bukti parasit malaria (antigen) dalam darah manusia. RDT merupakan deteksi handal dan cepat untuk mendeteksi infeksi malaria bahkan di daerah terpencil dengan akses terbatas ke layanan mikroskop berkualitas baik. ${ }^{9,10}$ RDT dapat mempermudah dan mempercepat mendiagnosis penyakit malaria dibandingkan menggunakan mikroskop karena menggunakan RDT tidak membutuhkan tenaga kerja yang banyak atau keahlian khusus, sedangkan pemeriksaan mikroskopik membutuhkan tenaga kerja yang memiliki keahlian khusus. ${ }^{10}$

Desa Mubune yang terletak di Kecamatan Likupang Barat merupakan salah satu desa di Kecamatan Likupang yang dilaporkan terdapat banyak penderita demam yang dicurigai malaria secara klinis. Fasilitas Kesehatan di Kecamatan Likupang Barat hanya terdapat satu Puskemas yaitu Puskesmas Mubune dan belum memiliki laboratorium dan fasilitas yang memadai untuk mendeteksi malaria.

Penelitian ini bertujuan untuk membandingkan efektifitas rapid diagnostic test (RDT) dengan pemeriksaan mikroskopik 
yang merupakan baku emas diagnostik malaria pada masyarakat yang menderita malaria klinis di Puskesmas Mubune Likupang Barat.

\section{METODE PENELITIAN}

Penelitian ini menggunakan rancangan uji diagnostik untuk mendapatkan sensitifitas dan spesifitas dengan menggunakan pemeriksaan rapid diagnostic test (RDT) dan pemeriksaan mikroskopik. Penelitian dilakukan selama 4 bulan yaitu September 2015-Januari 2015 berlokasi di Kecamatan Likupang Barat. Subjek penelitian ini ialah penderita dengan gejala malaria klinis.

Variabel penelitian ini meliputi jumlah true positive (TP), jumlah true negative (TN), jumlah false positive (FP) dan jumlah false negative (FN). True positive merupakan jumlah sampel yang dideteksi positif plasmodium pada pemeriksaan sediaan darah tebal dan dinyatakan benar pada pemeriksaan RDT sedangkan true negative merupakan jumlah sampel yang dideteksi negatif plasmodium pada pemeriksaan sediaan darah tebal dan dinyatakan benar pada pemeriksaan RDT. False negative merupakan jumlah sampel yang dideteksi negatif plasmodium pada pemeriksaan sediaan darah tebal dan dinyatakan positif pada pemeriksaan RDT. False negative merupakan jumlah sampel yang dideteksi negatif plasmodium pada pemeriksaan sediaan darah tebal dan dinyatakan benar pada pemeriksaan RDT (Tabel 1). Pene- litian ini menggunakan pemeriksaan RDT, serta pemeriksaan hapusan darah tebal dan hapusan darah tipis.

Tabel 1. Variabel penelitian

\begin{tabular}{|c|c|c|c|c|}
\hline & & \multicolumn{3}{|c|}{$\begin{array}{l}\text { Pemeriksaan mikroskopik } \\
\text { sediaan darah tipis }\end{array}$} \\
\hline & & Positif & Negatif & Total \\
\hline \multirow{2}{*}{ RDT } & Positif & $\mathrm{TP}$ & FP & $\mathrm{TP}+\mathrm{FP}$ \\
\hline & Negatif & $\mathrm{FN}$ & $\mathrm{TN}$ & $\mathrm{FN}+\mathrm{TN}$ \\
\hline Total & & $\mathrm{TP}+\mathrm{FN}$ & $\mathrm{FP}+\mathrm{TN}$ & \\
\hline
\end{tabular}

\section{HASIL PENELITIAN}

Tabel 2 memperlihatkan perbandingan hasil pemeriksaan RDT dan pemeriksaan mikroskopik 38 sampel darah penderita dengan malaria klinis. Terdapat 2 sampel yang positif plasmodium.

Tabel 2. Perbandingan hasil pemeriksaan RDT dan pemeriksaan mikroskopik sediaan darah tipis

\begin{tabular}{lllll}
\hline & & \multicolumn{2}{l}{$\begin{array}{l}\text { Pemeriksaan } \\
\text { mikroskopik } \\
\text { darah tipis }\end{array}$} & sediaan \\
\hline & & Positif & Negatif & Total \\
\hline \multirow{2}{*}{ RDT } & Positif & 2 & 1 & 3 \\
\cline { 2 - 5 } & Negatif & 1 & 34 & 35 \\
\hline $\begin{array}{l}\text { Total } \\
\text { sampel }\end{array}$ & 3 & 35 & 38 \\
\hline
\end{tabular}

Tabel 3 menyajikan perbandingan hasil pemeriksaan RDT dan pemeriksaan mikroskopik pada subyek penelitian dengan hasil yang hampir serupa.

Tabel 3. Perbandingan hasil pemeriksaan RDT dan pemeriksaan mikroskopik subjek

\begin{tabular}{cccccc}
\hline No & Nama sampel & $\begin{array}{c}\text { Pemeriksaan } \\
\text { mikroskopik }\end{array}$ & P. falciparum & PDT & vivax \\
\hline 1 & $\# 01$ & Negatif & - & - & Ket \\
2 & $\# 02$ & Negatif & - & - & TN \\
3 & $\# 03$ & Negatif & - & - & TN \\
4 & $\# 04$ & Negatif & - & - & TN \\
5 & $\# 05$ & Negatif & + & - & FN \\
6 & $\# 06$ & Negatif & - & - & TN \\
7 & $\# 07$ & Negatif & - & - & TN \\
8 & $\# 08$ & Negatif & - & - & TN \\
9 & $\# 09$ & Negatif & - & - & TN \\
10 & $\# 10$ & Negatif & - & - & TN \\
11 & $\# 11$ & Negatif & - & - & TN \\
12 & $\# 12$ & P. falciparum & - & - & FP \\
13 & $\# 13$ & Negatif & - & - & TN \\
\hline
\end{tabular}


Ritung, Pijoh, Bernadus:Perbandingan efektivitas Rapid diagnositic test ...

\begin{tabular}{llllll}
\hline 14 & $\# 14$ & Negatif & - & - & TN \\
15 & $\# 15$ & Negatif & - & - & TN \\
16 & $\# 16$ & Negatif & - & - & TN \\
17 & $\# 17$ & Negatif & - & - & TN \\
18 & $\# 18$ & Negatif & - & - & TN \\
19 & $\# 19$ & Negatif & - & - & TN \\
20 & $\# 20$ & P.vivax & - & + & TP \\
21 & $\# 21$ & Negatif & - & - & TN \\
22 & $\# 22$ & Negatif & - & - & TN \\
23 & $\# 23$ & Negatif & + & - & FN \\
24 & $\# 24$ & Negatif & - & - & TN \\
25 & $\# 25$ & Negatif & - & - & TN \\
26 & $\# 26$ & Negatif & - & - & TN \\
27 & $\# 27$ & Negatif & - & - & TN \\
28 & $\# 28$ & Negatif & - & - & TN \\
29 & $\# 29$ & Negatif & - & - & TN \\
30 & $\# 30$ & Negatif & - & - & TN \\
31 & $\# 31$ & Negatif & - & - & TN \\
32 & $\# 32$ & P. falciparum & - & - & FP \\
33 & $\# 33$ & Negatif & - & - & TN \\
34 & $\# 34$ & Negatif & - & - & TN \\
35 & $\# 35$ & Negatif & - & - & TN \\
36 & $\# 36$ & Negatif & - & - & TN \\
37 & $\# 37$ & Negatif & - & - & TN \\
38 & $\# 38$ & MIX & + & TP \\
\hline
\end{tabular}

\section{BAHASAN}

Dari hasil penelitian yang dilakukan selama 4 bulan di Wilayah Likupang Barat pada 38 orang dengan gejala malaria klinis hanya ditemukan 2 orang yang positif plasmodium setelah dilakukan pemeriksaan RDT. Hasil uji diagnostik terhadap sampel penelitian dengan pemeriksaan mikroskopik (baku emas) dan RDT didapatkan sensivitas sebesar $67 \%$ dan spesifitas sebesar 97\%. Maksud dari sensivitas disini ialah kemungkinan hasil alat diagnostik akan positif bila dilakukan pada sekolompok subjek yang sakit malaria. Berbeda dengan spesifitas yang bertujuan untuk menunjukkan kemampuan alat diagnostik menentukan bahwa subjek tidak sakit malaria.

Pada penelitian ini, sensivitas dari RDT menunjukkan angka $67 \%$ kemungkinan dikarenakan kesalahan mendiagnosis dan faktor daerah endemis sedangkan pada spesifitas didapatkan hasil $97 \%$ (sisa 3\% nya disebabkan karena terdapat 1 sampel yang termasuk false positive) bisa dikarenakan oleh beberapa hal antara lain kesalahan dalam pembacaan mikroskopik yang membutuhkan kemampuan tinggi ataupun disebabkan oleh jumlah parasit malaria yang rendah. Selain itu dapat pula disebabkan oleh adanya sistem imun terhadap parasit malaria yang tetap bertahan beberapa waktu dalam darah dan didteksi positif dengan RDT.

Pemeriksaan RDT memang mudah, cepat dan relatif sederhana dalam melakukan pemeriksaan malaria, tetapi RDT mempunyai kelemahan yaitu tidak dapat mendeteksi kepadatan parasit yang rendah. RDT hanya dapat membaca kehadiran parasit sebesar 40-100 parasit per mikroliter darah sedangkan pemeriksaan mikroskopik dapat membaca kehadiran parasit di dalam darah sampai 5-10 parasit per mikroliter darah. ${ }^{11}$

Pada penelitian ini didapatkan 34 sampel yang benar-benar dinyatakan negatif pada RDT dan dinyatakan juga pada mikroskopik. Selain itu didapatkan sampel yang dinyatakan positif pada RDT tetapi dinyatakan negatif pada mikroskopik. Hal itu mungkin disebabkan oleh kesalahan kerja atau alat tersebut sudah kadaluarsa.

Hasil penelitian ini sejalan dibandingkan dengan penelitian dari Siahaan di Medan yang melaporkan nilai sensitivitas 
pemeriksaan RDT rendah walaupun spesifitasnya masih tergolong baik. ${ }^{12}$ Penelitian yang dilakukan oleh Vanderjagt ${ }^{13}$ mendapatkan hasil sensitivitas RDT yang kurang dari $50 \%$. Hal ini dikarenakan sensitivitas RDT dipengaruhi oleh kepadatan parasit. Pada kepadatan parasit yang rendah, sensitivitas RDT menjadi berkurang $(<500$ parasit/ml). ${ }^{14,15}$

Pada dasarnya kelemahan RDT dapat diantisipasi dengan cara mengikuti petunjuk penyimpanan dan penggunaan alat sesuai dengan anjuran. Keakuratan hasil positif yang didapat dari pemeriksaan RDT sebesar $67 \%$ dipengaruhi antara lain karena daerah yang endemis. Oleh sebab itu setelah dilakukan pemeriksaan RDT dilanjutkan dengan pemeriksaan mikroskopik agar dapat mengetahui $100 \%$ dengan pasti pasien tersebut terdiagnosis malaria, sehingga dapat sembuh secara total dan dapat membantu menekan angka rekurensi.

Limitasi penelitian ini antara lain jumlah sampel dan jumlah RDT yang terbatas diakibatkan karena keterbatasan waktu dan dana penelitian yang mungkin memengaruhi hasil penelitian

\section{SIMPULAN}

Berdasarkan hasil penelitian ini dapat disimpulkan bahwa pemeriksaan rapid diagnostic test (RDT) menunjukkan efektivitas dan kecepatan dalam mendiagnosis malaria yang cukup baik, hampir sama dengan pemeriksaan mikroskopik.

Pemeriksaan RDT memperlihatkan efektivitasnya untuk digunakan sebagai metode pemeriksaan malaria alternatif yang sangat dibutuhkan terutama di daerah yang kekurangan tenaga laboratorium dan untuk kepentingan surveilans.

\section{SARAN}

Penggunaan RDT sebaiknya di sebarluaskan ke daerah yang kekurangan laboratorium dan belum memiliki fasilitas yang memadai agar penduduk daerah sekitar dapat cepat terdiagnosis penyakit malaria.

Penggunaan pemeriksaan mikroskopik sebagai sarana follow-up setelah pasien sembuh secara klinis karena DNA masih tetap terdeteksi dengan RDT agar dapat mencegah rekurensi yang dapat dialami penderita yang sudah sembuh.

\section{DAFTAR PUSTAKA}

1. Hadidjaja P, Margono SS. Dasar Parasitologi Klinik (1st ed). Jakarta: Badan Penerbit FKUI, 2011.

2. Sudoyo A, Setyohadi B, Alwi I. Buku Ajar Ilmu Penyakit Dalam. Jakarta: FKUI, 2006.

3. Fernandez M, Bobb B. About malaria. EMedicine. 2006. Available From [URL]: http://www.emedicine.com/emerg/topic3 05.htm

4. Sutanto I, Ismid IS, Syarifudin PK, Sungkar, Staf Pengajar FKUI. Parasitologi Kedokteran (4th ed). Jakarta: Bagian Parasitologi FKUI, 2008.

5. Harijanto PN, Nugroho A, Gunawan C. Malaria, dari Molekular ke Klinis (2nd ed). Jakarta: EGC, 2009.

6. Harijanto PN. Malaria. In: Harijanto PN, editor. Buku Ajar Ilmu Penyakit Dalam, Jilid III, Jakarta: Departemen Ilmu Penyakit Dalam Fakultas Kedokteran Universitas Indonesia, 2006.

7. Prabowo A. Malaria Mencegah dan Mengatasinya Cetakan II. Jakarta: Puspa Swara, 2008.

8. Harijanto PN. Malaria: epidemiologi, patogenesis, manifestasi klinis, penanganan. Jakarta: EGC, 2000

9. Mtove G, Hendriksen ICE, Amos B, Mrema H, Mandia H, Manjurano A, et al. Treatment guided dy rapid diagnostic tests for malaria in Tanzanian children: safety and alternative bacterial diagnoses. Malaria Journal. 2011;10:290.

10. Arum IL, Purwanto AP, Arfi S, Tetrawindu H, Octora M, Mulyanto, Amanukarti, et al. Uji diagnostik Plasmodium malaria menggunakan metode imunokromatografi diperbandingkan dengan pemeriksaan mikroskopis. Indonesian Journal of Clinical Pathology and Medical Laboratory 2006;12:118-22.

11. Gandahusa S, Ilahude HD, Pribadi W, Staf pengajar FKUI, editors. Parasitologi Kedokteran (3rd ed). Jakarta: FKUI, 2006.

12. Siahaan L. Perbandingan rapid diagnostic test (RDT) dan pemeriksaan mikroskopik pada diagnosa malaria di daerah endemis malaria. Kesmas. 2011;5(6): 250-3.

13. VanderJagt TA. Comparison of the optimal rapid test and microscopy for detection of malaria in pregnant women in Nigeria. Tropical Medicine and International Health. 2005;10 (1):39-41. 
Ritung, Pijoh, Bernadus:Perbandingan efektivitas Rapid diagnositic test ...

14. Coleman RE. Short report: failure of the optimal rapid malaria test as a tool for the detection of asymptomatic malaria in an area of Thailand endemic for plasmodium falciparum and plasmodium vivax. Am J. Trop Med Hyg. 2002; 67(6): 563-5.
15. Gonul A, Mustafa U, Adnan S, Ozcan E. Diagnostic performance characteristics of rapid diagnostic test for plasmodium vivax malaria. Meminst Oswaldo Cruz. 2001;96(5): 683-6. 